\title{
FERTILIZER POLICY DEVELOPMENT IN NEPAL
}

Ram Krishna Shrestha, MSc. ${ }^{1}$

\begin{abstract}
Fertilizer is a vital input for agriculture production. With the growing popularity of modern agriculture, fertilizer consumption in Nepal has been increasing over the years. Since, Nepal does not produce any fertilizers, demand for fertilizers are being met through formal and informal imports. Over the years, fertilizer policy changes have been observed several times in a bid to satisfy farmers' demand for quality fertilizers. While fertilizer policy change of deregulating the fertilizer trade initially produced positive impact in overall supply situation, deregulation policy could not largely ensure the supply of quality fertilizers in required quantity and time. Re-introducing subsidy regime in chemical fertilizer by the government's recent decision could be considered as a positive development towards meeting farmers demand for quality fertilizer. However, given the quota of subsidized fertilizer, which is far less than the actual demand, the problem of supply is likely to continue. To address current problem of short supply government should increase the quota at least up to three hundred thousand metric tons. Moreover, Ministry of Agriculture and Cooperatives should come up with a long-term plan aiming at sustainable management of soil fertility.
\end{abstract}

Key words: Fertilizer subsidy, fertilizer deregulation, fertilizer import

\section{INTRODUCTION}

Fertilizer is a vital input for agriculture production. It not only plays direct role in increasing production but also enhances efficiency of other inputs like irrigation and seeds. Twenty-year Agriculture Perspective Plan (APP), which is in implementation since 1997 has identified chemical fertilizer as an engine of agri. growth. Fertilizer is expected to contribute 64 to 75 percent of the total envisaged agriculture growth target of APP. APP has envisaged an increase in fertilizer usage from $31 \mathrm{~kg}$ nutrient/ hectare of the base year 1995 to $131 \mathrm{~kg}$ nutrient/ hectare by 2017.

The Agriculture Sector Performance Review (ASPR) survey carried out in 2000/01 estimated fertilizer usage to be $58 \mathrm{Kg}$ nutrient/ hectare (ANZDEC, 2002). In another study conducted by Oxford Policy Management (OPM), UK in 2001-2002 for MOAC also estimated average application rate of $56 \mathrm{Kg}$ nutrient/hectare (OPM, 2003). Table 1 shows the average fertilizer use per household to be $100.4 \mathrm{~kg}$ as suggested by the fertilizer use study 2002 .

Table 1: Average Fertilizer Use per Household (kg / household)

\begin{tabular}{lcccccc}
\hline Regions & Cereals & Cash crops & Pulses & Fruits & Vegetables & Total \\
\hline Hills & 21.3 & 11.8 & 0.1 & 0.0 & 2.7 & 35.9 \\
Terai & 137.5 & 14.7 & 6.2 & 2.0 & 3.9 & 164.3 \\
Total & 79.7 & 13.3 & 3.2 & 1.0 & 3.3 & 100.4 \\
\hline
\end{tabular}

Source: Fertilizer Use Study, OPM, 2002.

The table also shows that fertilizer use in terai more than 4 times higher than that in the hills. The reasons are (a) ease of access (b) proximity to India, and (c) lower fertilizer prices that suggests the use of fertilizer is likely to increase with improvements in access to fertilizer (IDL Group, 2006). No other comprehensive survey on fertilizer usage has been conducted since then. However, the common sense dictates that the fertilizer usage is on the rise.

\footnotetext{
${ }^{1}$ Senior Agriculture Extension Officer, Ministry of Agriculture and Cooperatives
} 
Fertilizer in Nepal has always been a political commodity. Supplying adequate quantity of fertilizer to the farmers in the country has always been a challenge for the governments. Governments have changed their fertilizer policies many times in a bid to ensure smooth supply of fertilizers in the country. Recently, the government has re-introduced subsidy on chemical fertilizers on cost sharing basis. This new subsidy policy is in implementation. This paper highlights the current subsidy policy and latter's implementation status. Moreover, the paper also presents overview of fertilizer policy development in Nepal over the years.

\section{FERTILIZER POLICY DEVELOPMENT IN NEPAL}

Fertilizer sector development and policy intervention in Nepal can be broadly divided into three phases as discussed below:

\section{PHASE I -BEFORE 1973}

Fertilizer was introduced in Nepal in early fifties with some private traders importing small quantity of Ammonium Sulphate (AS) from India. This was followed by National Trading Limited importing AS from Russia up to the mid sixties. Until then the level of fertilizer use was quite low.

Systematic efforts of importation and distribution of fertilizers started with the establishment of Agriculture Input Corporation (AIC) under then Ministry of Agriculture in 1966. AIC, as a public sector enterprise, was responsible for procurement and distribution of chemical fertilizers in the country. Initially, it imported fertilizers from India. Later on, it started importing fertilizers from international market. After the introduction of AIC in fertilizer business, demand for and use of fertilizer started to increase. Until 1972, cost plus basis of price was adopted. With that concept price of fertilizers in the hills would be fixed higher than that of terai for obvious reason of the transportation costs to be incurred while transporting fertilizers to the hills. Later, with the increase in price in international market, the policy was slightly altered to adopt uniform pricing system. With this pricing system hills farmers would get fertilizers below the actual cost whereas the farmers in terai region would pay more than the actual cost to offset the cost of transportation.

\section{PHASE II- SUBSIDY REGIME FROM 1973/74 TO 1996/97}

With the rise in the price of fertilizers in the international market, the government decided to introduce price subsidy, and transport subsidy in selected high hills and mid-hills districts in 1973/74. The subsidy policy was brought in to serve two purposes; first, encourage farmers to use fertilizers by providing at relatively low price, and second, discourage outflow of fertilizers from Nepal to India by keeping price 15-20 percent higher than that of India. AIC would get the difference amount between the actual cost and selling price. With the growing demand for fertilizer within the country and continuous rise in price of fertilizers in the international market, then governments were forced to bear huge financial burden as subsidy allocation. Since the fertilizers in Nepal are considered as politically sensitive commodity, no government would bother to make price adjustment to reduce the burden of exchequer. This situation aggravated AIC's loss to the tune of 850 million rupees at one time as the governments continuously became unable to allocate adequate budget to meet the subsidy requirement. AIC became unable to import fertilizers as per the demand for resulting short supply. Farmers were seen queuing up in the retail outlets of AIC to buy a meager quantity of fertilizer.

Nepal started receiving fertilizers under grant aid from the countries like Germany, Canada, Japan and Finland in late sixties. Some countries stopped the supply after 1991/92, while others reduced the volume. The supply used to be substantial in early years but became only a small fraction of total import in recent years. The latest such support came under 2 KR Grant Aid from the Government of Japan in 2006 in which 5412 metric tons of Urea was received. 


\section{PHASE III- DEREGULATION OF FERTILIZER TRADE FROM 1997/98 TO 2007/08}

AIC, as a public sector enterprise, enjoyed monopoly in fertilizer trade for long time before the government decide to deregulate the fertilizer trade in 1997/98. There was full control of AIC in procurement and distribution of fertilizers. Sales price of fertilizers were regulated by the government. With the growing demand for fertilizer and rise in the price of the same, government failed to make adequate subsidy allocation. Subsequently, import and supply of fertilizers declined adversely affecting agriculture production.

Also prompted by ADB's loan condition for Second Agriculture Production Loan (SAPL), the government started deregulating the fertilizer trade in November 1997 with complete removal of subsidy in Diammonium Phosphate (DAP) and Muriate of Potash (MOP), and phase-wise removal of subsidy in Urea. The subsidy was completely removed after November 1999. The deregulation package involved: i) removal of monopoly of the AIC in fertilizer trade by allowing the private sector to import and distribute the fertilizers with equal treatment for both the parties, ii) time-bound phase out of fertilizer subsidies and iii) decontrolling fertilizer price.

Pursuant to fertilizer deregulation policy, Ministry of Agriculture and Cooperatives (MOAC) issued working policy to involve the private sector in the fertilizer trade. This policy paved way for private traders to stand at equal footing with AIC. To institutionalize the deregulation policy, and to regulate the business under the policy, the government promulgated Fertilizer Control Order, 1999 as per the Essential Commodity (Control) ACT, 1996. In line with the deregulation policy, National Fertilizer Policy, 2002 was formulated. Moreover, AIC was terminated to form two companies- 1) Agriculture Input Company Limited (AICL) responsible for fertilizer business and 2) National Seed Company Limited (NSCL) responsible for seed business - under the Company Act, 1996.

\section{FERTILIZER CONTROL ORDER 1999}

The main objective of Fertilizer Control Order (FCO) is to ensure quality of fertilizer supplied to the farmers with following salient features in it.

- quality control mechanism during import

- $\quad$ any legally registered private business firm can enter into fertilizer business

- quality control at retail level

- provision of fertilizer inspector for quality check

- $\quad$ quality control in production of fertilizer

NATIONAL FERTILIZER POLICY 2002

Objectives of the National Fertilizer Policy (NFP) 2002 are-

- provision of condition (policy and infrastructure management) for enhancing fertilizer consumption

- $\quad$ promotion of integrated plant nutrient management system (IPNS) for the efficient and balanced use of fertilizers.

and its salient features have been-

- broad definition of fertilizer to include three types of fertilizer- organic, chemical and microbial

- $\quad$ promotion of IPNMS to maintain soil fertility through minimizing soil degradation and likely negative impact of chemical fertilizer

- $\quad$ equal treatment to government, private and cooperatives firms involved in fertilizer business 
- $\quad$ elimination of price subsidy but continuation of transport subsidy for selected districts of high hills and mid hills

- provision of buffer stock to respond to the acute shortage of fertilizer during the main cropping season

- $\quad$ policy of encouraging domestic production of fertilizer and provision of making investment in fertilizer industries of neighboring countries.

After the government adopted fertilizer deregulation policy in 1997, supply from formal sources (AICL and private importers) improved only up to 1998/99. The reasons behind were retention of partial subsidy in Urea import before November 1999, and relatively favorable price structure prevailing in the international market. Supply, however, went down after 1999/2000 onwards as both AICL and private importers could not import big volume owing to price fluctuation in the overseas market. Moreover, both the parties had hard times in selling fertilizers as subsidized cheap Indian fertilizers and, other adulterated and substandard fertilizers were easily available in the free markets of accessible areas. Farmers did not bother checking quality of fertilizers as they were happy to receive fertilizers at much lower price than that of AICL and authorized private importers. In addition to that, overall supply situation in remote areas could not improve for the obvious reason of high cost of transportation. Thus, while supply situation could not be improved as was expected, widespread problems of fertilizer quality also surfaced. This situation prompted to revisit the deregulation policy to address the issues encountered.

\section{FERTILIZER DEMAND AND SUPPLY}

\section{FERTILIZER DEMAND}

Due to the lack of scientific system of projecting fertilizer demand it is difficult to estimate real demand.

of fertilizers in the country. Moreover, unofficial import of fertilizer from long-open border with India has also made it difficult to estimate fertilizer demand. Such informally traded fertilizers constitute major portion of fertilizers being used in Nepal. ASPR (2002) estimated about two-third of the total import of fertilizers in Nepal came from unofficial import from India (ANZDEC, 2002). Although it is not possible to maintain actual record of cross-border inflow of informally traded fertilizers, there is no sign of subside.

Table 2: Average annual growth percentage of fertilizer demand as per ASPR field survey report

\begin{tabular}{l|c|c|c|c}
\hline \multirow{2}{*}{$\begin{array}{l}\text { Annual Growth } \\
\text { Percentage }\end{array}$} & Urea & DAP & MOP & Overall \\
\cline { 2 - 5 } & 16 & 20.2 & 19.9 & 18.2 \\
\hline
\end{tabular}

Source : ANZDEC, 2002.

ASPR field survey conducted during 2000/01 estimated 18.2 percent annual growth of fertilizer demand in Nepal (Table 2). Table 3 shows the projected demand for the fertilizers for five years. The figure was based on the survey of few selected districts from the hills and terai. The annual growth percentage of fertilizer demand seems quite high. Moreover, it is hard to believe that growth percentage of Muriate of Potash (MOP) to be 19.9. In reality, demand for and use of MOP is far below than that of Urea and Diammonium Phosphate (DAP). No other such study has been conducted thereafter. So, it's not possible to triangulate the survey report. Fertilizer demand collected by the Ministry from the all 75 districts shows that there is a demand of 726 thousand metric tons of chemical fertilizer for the Nepalese fiscal year 2066/67.

Supply of fertilizers increased continuously until 1991/92 with exception in 1975/76. The year 1991/92 witnessed the highest sale with 185.8 thousand tons. Sales started declining 
after $1991 / 92$ primarily due to insufficient subsidy allocation by the government thereby hampering the import by AIC. However, average annual growth of fertilizer sale remained 8.74 percent during the pre-deregulation phase (Table 4).

Table 3: Projected fertilizers demand (MT) as per ASPR growth percentage

\begin{tabular}{c|c|c|c|c}
\hline FY & Urea & DAP & MOP & Total \\
\hline $2064 / 65$ & 253051.04 & 164621.74 & 15986.67 & 433659.45 \\
$2065 / 66$ & 293539.21 & 190961.22 & 18544.53 & 503044.96 \\
$2066 / 67$ & 340505.48 & 221515.01 & 21511.66 & 583532.15 \\
$2067 / 68$ & 394986.36 & 256957.41 & 24953.52 & 676897.29 \\
$2068 / 69$ & 458184.17 & 298070.60 & 28946.09 & 785200.86 \\
\hline
\end{tabular}

Table 4 : Sales of fertilizers before deregulation (,000 MT)

\begin{tabular}{l|c|c|c|c|c}
\hline Year & Sale & Growth percentage & Year & Sale & Growth percentage \\
\hline $70 / 71$ & 17.73 & & $84 / 85$ & 100.12 & 15.19 \\
$71 / 72$ & 25.43 & 43.43 & $85 / 86$ & 102.2 & 2.08 \\
$72 / 73$ & 32.05 & 26.03 & $86 / 87$ & 105.74 & 3.46 \\
$73 / 74$ & 36.78 & 14.76 & $87 / 88$ & 121.23 & 14.65 \\
$74 / 75$ & 36.39 & -1.06 & $88 / 89$ & 131.95 & 8.84 \\
$75 / 76$ & 31.13 & -14.45 & $89 / 90$ & 158.8 & 20.35 \\
$76 / 77$ & 37.84 & 21.55 & $90 / 91$ & 168.55 & 6.14 \\
$77 / 78$ & 45.23 & 19.53 & $91 / 92$ & 185.8 & 10.23 \\
$78 / 79$ & 45.59 & 0.80 & $92 / 93$ & 169.767 & -8.63 \\
$79 / 80$ & 50.29 & 10.31 & $93 / 94$ & 148.413 & -12.58 \\
$80 / 81$ & 54.29 & 7.95 & $94 / 95$ & 176.688 & 19.05 \\
$81 / 82$ & 56.44 & 3.96 & $95 / 96$ & 133.25 & -24.58 \\
$82 / 83$ & 73.73 & 30.63 & $96 / 97$ & 122.223 & -8.28 \\
$83 / 84$ & 86.92 & 17.89 & Average annual growth & 8.74 \\
\hline
\end{tabular}

Source: Agri. Input Supply Monitoring Section, MOAC

Table 5 : Sales of Fertilizers after Deregulation (,000 M.T)

\begin{tabular}{c|c|c|c|c}
\hline Year & AICL & Private & Total & Growth rate \\
\hline $1997 / 98$ & 91.178 & 17.55 & 108.73 & \\
$1998 / 99$ & 88.35 & 68.477 & 156.83 & 44.24 \\
$1999 / 2000$ & 71.46 & 76.727 & 148.19 & -5.51 \\
$2000 / 01$ & 45.22 & 101.145 & 146.37 & -1.23 \\
$2001 / 02$ & 39.358 & 101.408 & 140.77 & -3.83 \\
$2002 / 03$ & 70.746 & 103.636 & 174.38 & 23.88 \\
$2003 / 04$ & 20.493 & 118.265 & 138.76 & -20.43 \\
$2004 / 05$ & 31.811 & 90.895 & 122.71 & -11.57 \\
$2005 / 06$ & 13.295 & 78.258 & 91.55 & -25.39 \\
$2006 / 07$ & 25.169 & 65.679 & 90.85 & -0.77 \\
$2007 / 08$ & 6.646 & 47.107 & 53.75 & -40.83 \\
$2008 / 09$ & 7.133 & 8.325 & 15.458 & -71.13 \\
& Average annual growth & & -10.23 \\
\hline
\end{tabular}

Source: Agri. Input Supply Monitoring Section, MOAC

Even after the deregulation, supply situation could not improve. As shown in Table 5, total sales declined every year with some exception resulting negative average annual growth of 10.23 percent. The fall in supply after 1999 was mainly due to rise in price of fertilizer in international market and uncontrolled inflow of cheap Indian fertilizers. While supply from 
the formal sources saw steady decline, overall supply increased dramatically, thanks to unofficially imported fertilizers through porous Indo-Nepal border. Although it is not possible to make estimation of cross-border inflow of fertilizers, it is estimated to be twothird of the total supply volume. Agriculture Sector Performance Review (ASPR) estimated that out of the total import of 430 thousand tons of fertilizers in 2000/01, approximately 280 thousand tons was imported unofficially from India. Moreover, a couple of mixed fertilizer manufacturing plants have been established in the country in post deregulation phase. They consume, as the raw materials, ready-to-use fertilizers such as Urea, DAP, Super Phosphates imported from India and the third countries. These plants are contributing only small quantity of fertilizers to the total supply yet putting pressure to the already imported ready-to-use fertilizers in the country. On the other hand, increasing complaints from the farmers of such mixed fertilizers being sub-standard quality have questioned the need to promote such plants. In a nutshell, it can be said that change in fertilizer policy in 1997/98 did not improve supply situation as expected.

\section{CURRENT POLICY ON FERTILIZER SUBSIDY}

\section{GENESIS OF CURRENT POLICY}

Deregulation policy largely failed to bring desirable impact on improving supply situation and quality control of fertilizer. External factors such as rise in price in international market, heavy government subsidy being enjoyed by the Indian farmers, and uncontrolled inflow of illegally traded fertilizers aggravated the situation. Due to excessive rise in price small and marginal farmers could not afford quality fertilizers. Farmers were forced to use fertilizers of unknown quality available in the free market albeit at cheaper price.

Farmers' voices have been loud in recent years regarding assured supply and quality of fertilizers. Moreover, they are helpless before free inflow of cheap Indian agriculture products produced under heavy government subsidy. Our farmers are unable to compete with such products as they are operating with extremely adverse condition without any incentive to go for production. In many cases, they can hardly recover cost of production by selling their produces. The issue has also been raised by the politicians, civil society and other members of the society.

To address the issue of fertilizer sector, MOAC came up with the proposal to review the existing fertilizer policy in October 2008 with the objective of making fertilizer supply and distribution arrangement more effective. Accordingly, MOAC forwarded the proposal to Council of Ministers (COM) in November 2008. COM gave approval, in principle, to the proposal to provide support in chemical fertilizers targeting small and marginal farmers. As per the decision of the COM, MOAC and Ministry of Finance in the leadership of Secretaries of the respective ministries developed operational modality of the subsidy administration and submitted the same to the COM. The government finally endorsed the modality on March 25, 2009.

Salient features of government's latest decision on providing chemical fertilizers at subsidized rate

IMPORT AND SUPPLY:

- $\quad$ provision of fixing sales price at 20-25 percent higher than that of India for five import points - Biratnagar, Birgunj, Bhairahawa, Nepalgunj and Dhangadi.

- $\quad$ provision of a high level 'Subsidy Allocation Management Committee' under the chairmanship of Secretary at MOAC. The committee is mainly responsible for fixing sales price of the five import points.

- $\quad$ AICL will be the sole agency to import fertilizer to be distributed at subsidized rate. 
- $\quad$ AICL will receive difference amount between actual cost price of importing fertilizers from outside the country, and the sales price at import points.

- retail price for farmers will be sales price at the import points plus transportation cost up to the delivery point.

- Annually 100 thousands metric tons of fertilizers will be imported under this scheme.

DISTRIBUTION :

- Subsidized fertilizers will be provided for technically required amount for three crops a year.

- Subsidized fertilizers will be available for up to 0.75 hectare in the hills and 4 hectare terai.

- Subsidized fertilizers will be sold through the offices of AICL, and cooperatives organizations and cooperative shops.

- $\quad$ 'Fertilizer Supply and Distribution Management Committee' headed by the Chief District Officer of the respective district will look after the affairs related to supply and distribution of subsidized fertilizers at the district level.

\section{ON-GOING AND PIPELINE PROJECTS IN THE FERTILIZER SECTOR}

- Grant Assistance for Nepal Government to Increase Food Production for Underprivileged Farmers: A Japanese Study Mission was fielded during October, 2009 in course of preparation for the possible grant aid to provide chemical fertilizers to Nepal during Japanese fiscal year 2009. The team consulted the concerned personnel from the government and non-government sectors dealing with fertilizers in the country. At the end of the Mission a Minute of Discussion was signed between the two governments. Recently, Government of Japan has approved grant amount of 490 million Japanese Yen for providing chemical fertilizers to Nepal under the aforesaid grant assistance during the Japanese fiscal year 2009. The Grant Agreement is due to be signed in March this year.

- FAO TA Aimed at Prescribing Sustainable Fertilizer Policy: A FAO TA Mission visited Nepal on December 2009 with a view to reviewing government's current fertilizer policy and latter's implementation. The report on findings of the Mission has already been made available to the Ministry. Besides making policy recommendations, the report also highlights the possible project ideas for the sustainable fertilizer sector development in the country. FAO has been learnt to negotiate the projects to be funded by the donor agencies in days to come.

- World Bank Supported Irrigation and Water Resource Management Project: This ongoing project is supporting the cost of transporting fertilizers up to the Agriculture Service Centers located in various parts of a district with the objective of increasing food production in 23 food deficit hilly districts.

\section{ISSUES AND CHALLENGES}

Nepal has been facing problems in ensuring supply of quality fertilizer as per the farmers' demand since long before. Major issues and the challenges of the present day fertilizer sector are discussed below.

\section{IMPORT/SUPPLY}

- With the reintroduction of price subsidy on chemical fertilizers the private sector has virtually lost the level playing ground with AICL as the former is not entitled to import and distribute the subsidized fertilizers. Genuine private fertilizer importers/traders can not compete with the subsidized stuff and that with unofficially imported 
subsidized Indian fertilizers and other substandard fertilizers. This has jeopardized the government's earlier made commitment of involving private sector in fertilizer business, which was one of the major objectives of NFP, 2002.

- Subsidy is available for only 100 thousand metric tons, which is far less amount than the actual demand. Rest of the demand is being met through the unofficial import from India. Any change in Indian government gesture on regulating illegal cross-border trade would bring a shock to the internal fertilizer market.

- Meeting the peak season demand of fertilizers has been a challenge even after the reintroduction of subsidy. Import of fertilizers from India under IPP scheme and that through global tender normally takes 3 to 5 months hampering timely supply at the peak requirement time.

\section{DISTRIBUTION}

- It is quite cumbersome to administer the provision of providing subsidized fertilizers up to 4 ha and 0.75 ha of land in terai and hills respectively. Producing valid proof of the land ownership to get meager quantity sometimes may not be both feasible and economical. On the other hand, landless tenants are denied the entitlement of buying the subsidized fertilizer stuff.

- Only cooperatives can sell subsidized fertilizers as per the current subsidy policy. Since in most of the cases cooperatives are not operating in all parts of the districts, farmers from the areas, with no cooperatives operating, are either unable to enjoy the subsidized stuff or they are forced to make even up to two days walk to get the district headquarters or the nearest cooperatives to buy the subsidized fertilizers.

- Especially in the hilly districts, even if there are cooperatives operating, there are unable to purchase the fertilizers owing to their poor financial capacity resulting constrained supply in these districts.

- District based 'Fertilizer Supply and Distribution Management Committee' is responsible for managing affairs related to supply and distribution of subsidized fertilizers. Monitoring of supply and distribution is an important aspect. There is a need that the committee acts promptly to ensure free, fair and smooth supply and distribution of the fertilizer in the district. However, the committee is operating with no logistic supports whatsoever for its effective functioning thereby resulting poor monitoring of supply and distribution of the subsidized fertilizers in the district.

\section{QUALITY CONTROL}

- There is uncontrolled inflow of unofficially traded adulterated and substandard fertilizers from India. Some private traders are blamed to repack such low quality fertilizers to give popular brands like that of AICL and other Indian fertilizer company thereby cheating the farmers. This is a matter of grave concern, and checking this problem is one of the major challenges of the present day fertilizer sector. MOAC alone can not control such illegal transaction given the limited number of manpower, that too, operating with only little legal and technical expertise, and that with poor logistic facilities.

- Import and distribution of organic and bio-fertilizers both in solid and liquid forms has been seen growing in an unprecedented manner in recent days. FCO, 1999 and NFP 2002 do not have sufficient provisions to regulate the import and distribution of such fertilizers.

\section{USAGE}

- Majority of the farmers are inclined towards using only nitrogenous fertilizers like Urea or they are disproportionately using $\mathrm{N}, \mathrm{P}$ and $\mathrm{K}$ fertilizers mainly due to relatively low 
price of Urea and ignorance about the balanced use of fertilizers. The excessive use of nitrogenous fertilizers and unbalanced nutrient supply has increased soil acidity and deterioration of soil physical condition. Excessive use of nitrogenous fertilizer is also responsible for deterioration of underground water quality.

- Excessive use of nitrogenous fertilizers is also responsible for increased emission of nitrous oxide, one of the major gases responsible for global warming, and resultant effect on climate change.

\section{DATABASE MANAGEMENT}

- Lack of any mechanism to estimate total fertilizer requirement of the country based on crop requirement.

- Difficult to project demand for fertilizer in the country mainly due to prevailing unofficial import from India through cross-border illegal trade.

\section{CONCLUSION}

Chemical fertilizer is an important input for agriculture production. Nepal does not produce any fertilizers, so it has to depend on import from India and third countries. Fertilizer has been a commodity of political importance in Nepal for long time now. Often, the government is in pressure of dealing with farmers' demand for timely supply of quality fertilizers.

Changes in fertilizer policy over the time have produced mixed results. In the past, when there was subsidy on chemical fertilizer, relatively good quality stuff was supplied, but the supply was constrained mainly due to inadequate budgetary allocations. On the other hand, when deregulation of fertilizer was practiced and subsidy was lifted, supply situation performed relatively better but then issues of quality surfaced. Moreover, overall fertilizer trade and supply has been heavily influenced by the price in the international market, and illegal import of subsidized and other substandard fertilizers from India.

Despite the changes in fertilizer policy time and again, large fraction of fertilizer demand is still being met through the unofficially imported fertilizers from India. The situation is expected to continue until India takes policy of stern border regulation. That very day, Nepal would fall into an unprecedented crisis of supplying fertilizers to its farmers. To overcome such situation, voices are often heard as why not to establish fertilizer factory within the country. However, studies in the past suggested that establishing fertilizer plant in the country is not feasible. Thapa (2006) cited three main reasons for. Firstly, Nepal has no raw feed stocks or materials such as naptha, petroleum, coal, natural gas, phosphates or potash minerals. Secondly, electric power in Nepal is very costly as compared to the neighbours. Finally, the size of domestic demand is very small compared to an economic size of the fertilizer plant. Government's recently announced policy has come as a positive development in supporting farmers. However, given the amount of fertilizers to be provided in subsidized rate, problem of supply seems to remain in days to come.

\section{RECOMMENDATION}

Based on present day issues of fertilizer sector mentioned above and conclusion drawn, the following recommendation are made:

- If the government recent policy of subsidizing fertilizers is to continue, subsidy amount should be allocated for at least 300 thousand tons. Moreover, it is better to fix the allocation ceiling for subsidy rather than fixing the supply volume (100 thousand tons at present),

- There should be provision of fixing selling price of import points up to around $50 \%$ of the Indian retail price. This provision, on the one hand will improve supply situation. 
On the other hand, it will reduce the burden of exchequer. Moreover, there should be flexibility to fix the selling price of import points based on type of fertilizers and pre specified crops,

- Government should engage in negotiation with Indian government to cease the all time problem of fertilizers by entering into agreement that ensures smooth supply from India. Negotiation should also consider the possibility of Nepal government receiving subsidized fertilizers from the Indian counterpart,

- Possibility of making share investment in new fertilizer factories to be established in neighboring countries like India and Bangladesh should be explored without further delay,

- Subsidy in urea may be lifted or heavily curtailed down. Urea is comparatively cheaper than other fertilizers and no further promotion is needed to increase the use of the same. This would also encourage the farmers to make balanced use of NPK fertilizers,

- IPNMS should be aggressively introduced in the farming system through the agriculture extension system. Special campaign for compost preparation and use is need of the hour,

- $\quad$ Production and use of organic fertilizer should be encouraged and promoted. (Govt. has allocated 50 millions for the promotion of organic fertilizers and establishment of organic fertilizer factory for the FY 2066/67),

- Implement the fertilizer buffer stock provision as envisaged in NFP,

- Strengthen Agriculture Input Supply Monitoring Section of MOAC to play more effective roles in changed policy context,

- Infrastructural and institutional strengthening of $\mathrm{AICL}$ is quite necessary to ensure smooth import and distribution of the fertilizers in the country. Additional outlets should be opened in the areas with reliable road networks to satisfy the demand of needy farmers,

- Government should also mull over the possibility of involving Salt Trading Corporation Limited if former is to increase the volume of subsidy more than 200 thousand metric tons as AICL is seemed to be able to administer 200 thousand metric tons at the most given the present organizational capacity,

- $\quad$ District Agriculture Development Offices and Fertilizer Inspector should be provided with all the needed legal, technical and logistic services and facilities for the effective monitoring of fertilizer quality,

- A comprehensive and coordinated policy and program should be formulated and implemented to address the quality issues of fertilizer, and

- $\quad$ MOAC should develop a visionary plan to address the issues of fertilizer sector and ensure supply of quality fertilizer in the country.

- With rapid expansion of fertilizer trade in terms of diversified products and increased volume of transaction, malpractices and quality issues have been widespread. So, it is high time to regulate the sector through appropriate statutory arrangement.

\section{REFERENCES}

Agriculture Perspective Plan, 1995. Government of Nepal

ANZDEC, 2002 Nepal: Agriculture sector performance review (ADB TA No.3536-NEP), main report prepared for MOAC and Asian Development Bank. ANZDEC Limited: New Zealand.

MOAC, 1999. Fertilizer (Control) Order 2055. Government of Nepal, Ministry of Agriculture and Cooperative, Kathmandu, Nepal. 
IDL Group, 2006. APP Implementation status report (vol. I): Main Report prepared by NARMA Consultancy Pvt. Ltd. and SEEPORT Consultancy Pvt. Ltd. Nepal for the Government of Nepal.

MOAC, 2009. Lagat sahabhagita ko aadharma rasayanik malma sahayog upalabdha garaune sambandhi prastab (in Nepali), A policy paper about providing chemical fertilizers at subsidized rate on cost sharing basis endorsed by the Government of Nepal on 25th of March, 2009. Ministry of Agriculture and Cooperative, Kathmandu, Nepal.

MOAC, 2008. Statistical Information on Nepalese Agriculture, 2007/08. Ministry of Agriculture and Cooperatives, Kathmandu, Nepal.

NARMA, 2006. Impact of Fertilizer Deregulation Policy. Prepared by NARMA Consultancy Pvt. Ltd. Kathmandu for the Ministry of Agriculture and Cooperatives, Kathmandu, Nepal.

MOAC, 2002. National Fertilizer Policy 2058. Government of Nepal, Ministry of Agriculture and Cooperative, Kathmandu, Nepal.

OPM, 2003. Nepal fertilizer use study. A study funded by the UK Department for International Development (DFID). Kathmandu: Oxford Policy Management and Ministry of Agriculture and Cooperatives.

Thapa, Y.B., 2006. Constraints and approach for improving fertilizer supply for meeting domestic demand (policy paper 30). Government of Nepal, Ministry of Finance, Economic Policy Network, Kathmandu, Nepal.

Annex 1: Fertilizer Import by Source in the Last Ten Years (Metric tons) $(1998 / 99$ - 2008/09)

\begin{tabular}{|c|c|c|c|c|c|c|}
\hline Year & Name of Fertilizer & AICL & Private & $\begin{array}{c}\text { 2KR } \\
\text { (Japan's } \\
\text { Aid) }\end{array}$ & $\begin{array}{l}\text { Other } \\
\text { donors }\end{array}$ & Total \\
\hline $1998 / 99$ & $\begin{array}{l}\text { Urea } \\
\text { DAP } \\
\text { MOP } \\
\text { Ammonium Sulphate } \\
\text { Others } \\
\text { Total (MT) }\end{array}$ & $\begin{array}{l}77857 \\
50132\end{array}$ & 91049 & & 0 & $\begin{array}{r}168906 \\
50132\end{array}$ \\
\hline $1999 / 2000$ & $\begin{array}{l}\text { Urea } \\
\text { DAP } \\
\text { MOP } \\
\text { Ammonium Sulphate } \\
\text { Others } \\
\text { Total (MT) }\end{array}$ & $\begin{array}{l}30000 \\
10000\end{array}$ & $\begin{array}{l}61347 \\
31173\end{array}$ & $\begin{array}{c}7000 \\
14817 \\
1500 \\
\\
23317\end{array}$ & 0 & $\begin{array}{r}98347 \\
55990 \\
0 \\
1500 \\
0 \\
155837\end{array}$ \\
\hline $2000 / 01$ & $\begin{array}{l}\text { Urea } \\
\text { DAP } \\
\text { MOP } \\
\text { Ammonium Sulphate } \\
\text { Others } \\
\text { Total (MT) }\end{array}$ & $\begin{array}{l}24189 \\
30415\end{array}$ & $\begin{array}{l}76354 \\
12365\end{array}$ & $\begin{array}{c}11820 \\
10920 \\
5140\end{array}$ & & $\begin{array}{r}112363 \\
53700 \\
5140 \\
0 \\
0 \\
171203\end{array}$ \\
\hline $2001 / 02$ & $\begin{array}{l}\text { Urea } \\
\text { DAP } \\
\text { MOP } \\
\text { Ammonium Sulphate } \\
\text { Others } \\
\text { Total (MT) }\end{array}$ & 12500 & $\begin{array}{r}79350 \\
21004 \\
3000 \\
103354\end{array}$ & $\begin{array}{c}16220 \\
13820 \\
4300 \\
\\
34340\end{array}$ & & $\begin{array}{r}95570 \\
47324 \\
4300 \\
3000 \\
0 \\
150194\end{array}$ \\
\hline
\end{tabular}




\begin{tabular}{|c|c|c|c|c|c|c|}
\hline Year & Name of Fertilizer & AICL & Private & $\begin{array}{c}\text { 2KR } \\
\text { (Japan's } \\
\text { Aid) }\end{array}$ & $\begin{array}{l}\text { Other } \\
\text { donors }\end{array}$ & Total \\
\hline $2002 / 03$ & $\begin{array}{l}\text { Urea } \\
\text { DAP } \\
\text { MOP } \\
\text { Ammonium Sulphate } \\
\text { SSP } \\
\text { Total (MT) }\end{array}$ & 0 & $\begin{array}{c}45190 \\
28187 \\
\\
6662 \\
3400 \\
83439 \\
\end{array}$ & $\begin{array}{l}17830 \\
10255 \\
28085\end{array}$ & & $\begin{array}{r}63020 \\
38442 \\
0 \\
6662 \\
3400 \\
111524 \\
\end{array}$ \\
\hline $2003 / 04$ & $\begin{array}{l}\text { Urea } \\
\text { DAP } \\
\text { MOP } \\
\text { Ammonium Sulphate } \\
\text { SSP } \\
\text { NPK }(12: 32: 16) \\
\text { APS }(20: 20: 0: 13) \\
\text { Total (MT) }\end{array}$ & $\begin{array}{l}4134 \\
7000\end{array}$ & $\begin{array}{c}96146 \\
29399 \\
1100 \\
4639 \\
1498 \\
500 \\
4666 \\
137948\end{array}$ & $\begin{array}{l}7715 \\
9500\end{array}$ & & $\begin{array}{r}107995 \\
45899 \\
1100 \\
4639 \\
1498 \\
500 \\
4666 \\
166297\end{array}$ \\
\hline $2004 / 5$ & $\begin{array}{l}\text { Urea } \\
\text { DAP } \\
\text { MOP } \\
\text { Ammonium Sulphate } \\
\text { Others } \\
\text { Total (MT) }\end{array}$ & $\begin{array}{c}5370 \\
12081\end{array}$ & $\begin{array}{c}17161 \\
30726 \\
135 \\
4689 \\
12247 \\
64958 \\
\end{array}$ & & & $\begin{array}{r}22531 \\
42807 \\
135 \\
4689 \\
12247 \\
82409 \\
\end{array}$ \\
\hline $2005 / 6$ & $\begin{array}{l}\text { Urea } \\
\text { DAP } \\
\text { MOP } \\
\text { Ammonium Sulphate } \\
\text { Others } \\
\text { Total (MT) }\end{array}$ & $\begin{array}{l}0 \\
0 \\
0 \\
0 \\
0 \\
0\end{array}$ & $\begin{array}{c}35385 \\
25585 \\
\\
6475 \\
25343 \\
92788 \\
\end{array}$ & 6877 & 0 & $\begin{array}{r}42262 \\
25585 \\
0 \\
6475 \\
25343 \\
99665\end{array}$ \\
\hline $2006 / 7$ & $\begin{array}{l}\text { Urea } \\
\text { DAP } \\
\text { MOP } \\
\text { Ammonium Sulphate } \\
\text { Others } \\
\text { Total (MT) }\end{array}$ & $\begin{array}{c}14762 \\
9362 \\
\\
13880 \\
38004\end{array}$ & $\begin{array}{c}8467 \\
3914 \\
\\
2374 \\
27134 \\
41889\end{array}$ & 5440 & 0 & $\begin{array}{r}28669 \\
13276 \\
0 \\
2374 \\
41014 \\
85333\end{array}$ \\
\hline $2007 / 8$ & $\begin{array}{l}\text { Urea } \\
\text { DAP } \\
\text { MOP } \\
\text { Ammonium Sulphate } \\
\text { Others } \\
\text { Total (MT) }\end{array}$ & 4891 & $\begin{array}{c}2256 \\
719 \\
\\
9978 \\
24765 \\
37718\end{array}$ & 0 & 0 & $\begin{array}{c}7147 \\
719 \\
0 \\
9978 \\
24765 \\
42609\end{array}$ \\
\hline $2008 / 9$ & $\begin{array}{l}\text { Urea } \\
\text { DAP } \\
\text { MOP } \\
\text { Ammonium Sulphate } \\
\text { Others } \\
\text { Total (MT) }\end{array}$ & $\begin{array}{c}2497.1 \\
7496.0 \\
5\end{array}$ & $\begin{array}{l}2744.4 \\
2744.4\end{array}$ & 0 & 0 & $\begin{array}{c}4998.95 \\
0 \\
0 \\
2744.4 \\
2497.1 \\
10240.4 \\
5\end{array}$ \\
\hline
\end{tabular}

